\title{
New genera and species of cytheracean Ostracoda from the S. W. Atlantic
}

\author{
ROBIN WHATLEY, JOHN CHADWICK, ${ }^{2}$ DAVID COXILL ${ }^{1} \&$ NICHOLAS TOY ${ }^{1}$ \\ ${ }^{1}$ Micropalaeontology Division, Dept. of Geology, University College of Wales, \\ Aberystwyth, U.K. \\ ${ }^{2}$ Robertson Research International plc, Wellshead Industrial Estate, \\ Dyce, Aberdeen, Scotland, U.K.
}

\begin{abstract}
Five new genera of cytheracean Ostracoda are described from the S.W. Atlantic area. They are: Austrocytheridea and Papillosacythere, which belong to the Cytherideinae and Neocytherideinae respectively, and Austroaurila, Falklandia, and Meridionalicythere, which are all members of the Hemicytheridae.
\end{abstract}

\section{INTRODUCTION}

This paper forms part of a much larger study of the Recent Ostracoda of the Antarctic, sub-Antarctic, Falkland Islands and the coast and Continental Shelf of Tierra del Fuego, the Magellan Straits and the Argentinian, Uruguayan and southern Brazilian seaboard. The study is based on eulittoral and sublittoral samples collected by the senior author, assisted by Argentinian colleagues, during a number of excursions and expeditions made during 1970-1973. A large number of sediment samples from the Continental Shelf and the estuary of the Rio de La Plata were made available by the Hydrographic Service of the Argentine Navy.

The Bairdiacea, marine Cypridacea and the cytherid family Pectocytheridae from this material formed the basis of a Magister thesis written by Moguilevsky (MS, 1976). The cytheracean family Leptocytheridae were studied by Whatley \& Moguilevsky (1975). In 1984, the remainder of the material, together with additional samples provided by the British Antarctic Survey, was made the basis of three Magister theses at Aberystwyth. Coxill (MS, 1985) studied deep water and shelf faunas from the Antartic and South Scotia Sea and also those of the littoral and sublittoral of East Falkland. Toy (MS, 1985) studied the littoral faunas of Tierra del Fuego, both sides of the Magellan Straits and the Argentine Coast north to lat. $45^{\circ} \mathrm{S}$. and sediment samples from the Continental Shelf north to the same latitude. Chadwick (MS, 1986) worked on the Ostraco$\mathrm{da}$ of the Argentine littoral from lat. $45^{\circ} \mathrm{S}$. north to the estuary of the Rio de La Plata and from sediments from the Continental Shelf of northern Argentina, Uruguay and southern Brazil. He also studied a suite of samples from the estuary of the Rio de La Plata.

Details of the sampling localities and of the samples themselves can be found in the respective theses and these data will be published in a subsequent paper on the ecological and zoogeographical distribution of the
Ostracoda of the region. These studies yielded a rich and diverse fauna of podocopid ostracods. For example, Moguilevsky recorded 16 species, Coxill 97 species, Toy 90 species and Chadwick 104 species.

All figured types of new species are housed in the collections of the Department of Zoology, British Museum (Natural History) and other figured specimens are house in the Micropalaeontology Museum, Department of Geology at Aberystwyth. A representative collection of all the species dealt with in this paper will be deposited in the Museo de la Plata, Argentina.

\section{SYSTEMATIC DESCRIPTIONS}

Phylum Crustacea Pennant, 1777

Classs Ostracoda Latreille, 1806

Order Podocopida Müller, 1894

Suborder Podocopina Müller, 1894

Superfamily Cytheracea Müller, 1894 Family Cytherideidae Sars, 1925

Subfamily Cytherideinae Sars, 1925

Genus Austrocytheridea gen. nov.

Type species. Austrocytheridea dispersopunctata gen. et sp. nov.

Derivation of name. Latin, with reference to the apparent restriction of the genus to the South Atlantic.

Diagnosis. Large, subovate to subelliptical with distinct anteroventral incurvature. Anterior margin narrowly rounded with apex below mid-height; posterior bluntly pointed. Thick-shelled. Smooth except for small but deep, irregularly distributed punctae which contain normal pore canal openings. Hinge antimerodont, strongly developed with long terminal elements. Inner lamella of moderate width and with large anterior vestibulum; radial pore canals short, simple or rarely bifurcating, some 25 anteriorly. Four small rounded to oval, well-spaced adductor scars and a strongly 
"v"-shaped vertically disposed frontal scar. Strongly dimorphic.

Remarks. In its shape and outline, this genus resembles Ovocytheridea Grekoff, from the Cretaceous of Africa. The latter genus, however, differs in internal details, most importantly in its rather narrow avestibulate inner lamella. Some species of Cyamocytheridea Oertli are similar in shape but have a much less robustly developed median hinge element and a frontal scar which is more crescentic and which opens anteriorly rather than dorsally. Sarsicytheridea Athersuch, is similar internally but very different in shape. The genus is apparently monotypic and restricted to the southern S. W. Atlantic.

Austocytheridea dispersopunctata sp. nov. (Pl. 1, figs. 1-8)

Derivation of name. Latin, with reference to the widely spaced punctae.

Diagnosis. As for genus.
Holotype. Female right valve (1986, 507).

Material. 71 adults and juveniles including several live specimens.

Type Locality. From eulittoral algae in a small bay immediately to the west of Ushuaia, Beagle Channel, Tierra del Fuego, at approximately lat. $54^{\circ} 40^{\prime} \mathrm{S}$.; long. $68^{\circ} 0^{\prime} \mathrm{W}$. Recent.

Description. Large, laterally inflated, thick-shelled and strongly sexually dimorphic. Female subovate, male subelliptical and less inflated. Anterior margin narrowly rounded with apex below mid-height. Dorsal margin without cardinal angles; subumbonate in female, arcuate in male. Ventral margin biconvex, with distinct anteroventral oral incurvature. Posterior margin bluntly pointed to subrounded. Maximum length below mid-height; maximum height at mid-length; maximum width just behind mid-length. Valve surface smooth except for small but deep irregularly distributed punctae which are associated with normal pore canals, and very weak ventral ribs. Inner lamella wide anteriorly; narrow ventrally and posteriorly. Vestibulae at each

\section{Explanation of Plate 1}

Figs. 1-8. Austrocytheridea dispersopunctata gen. et sp. nov.

Fig. 1. Paratype, $q$ LV, $(1968,508)$, ext. lat. $(\times 65)$. Same sample as holotype.

Fig. 2. Paratype, $0^{x} \mathrm{LV},(1968,510)$, ext. lat. $(\times 65)$. Same sample as holotype.

Fig. 3. Holotype, $q$ RV, $(1986,507)$, ext. lat. $(\times 61)$. Eulittoral algae just west of Ushuaia, north shore of Beagle Channel, lat. $54^{\circ} 50^{\prime} \mathrm{S}$.

Fig. 4. Paratype, $\sigma^{\prime} \mathrm{Rv},(1986,511)$, ext. lat. $(\times 64)$. Eulittoral Cladophora, Puerto Porvenir, Magellan Straits coast of Chilean Tierra del Fuego, lat. $53^{\circ} \mathrm{S}$.

Fig. 5. Paratype, 이 LV, $(1986,508)$, int. $(\times 65)$. Same sample as holotype.

Fig. 6. Paratype, ơ LV, NT/Arg/Ad 10, ext. lat. $(\times 65)$. Same sample as holotype.

Fig. 7. Paratype, $q \mathrm{Rv},(1986,509)$, ext. lat. $(\times 62)$. Same sample as holotype.

Fig. 8. Paratype, $\Varangle$ RV, $(1986,509)$, int. $(\times 62)$. Same sample as holotype.

Figs. 9-13. Papillosacythere parallela gen. et sp. nov.

Fig. 9. Holotype, $\sigma^{7} \mathrm{RV},(1986,512)$, ext. lat. $(\times 100)$. Bahia Samboronbon, estuary of the Rio de La Plata, muddy silt, lat. $36^{\circ} 15^{\prime} 05^{\prime \prime} \mathrm{S}$.; long. $56^{\circ} 55^{\prime} 05^{\prime \prime} \mathrm{W} ., 4 \mathrm{~m}$.

Fig. 10. Paratype, $q$ c. JC/Arg $/ 173$, left ext. lat. ( $\times 96)$. Shelly sand, lat. $36^{\circ} 12^{\prime} 40^{\prime \prime}$ S.; long. $56^{\circ} 24^{\prime} 08^{\prime \prime} \mathrm{W} ., 21 \mathrm{~m}$. Fig. 11. Paratype, ơ LV, $(1986,513)$, ext. lat $(\times 96)$. Same sample as holotype.

Fig. 12. Holotype, int. $(\times 100)$.

Fig. 13. Paratype, juv. LV, $(1986,515)$, ext. lat. $(\times 111)$. Same sample as holotype.

Fig. 14. Paratype, juv. RV, $(1986,516)$, ext. lat. $(\times 122)$. Same sample as holotype.

Figs. 15-21. Austroaurile theeli (Skogsberg), 1928.

Fig. 15. O LV, NT/Arg/At 1, ext. lat. (×68). Eulittoral, Puerto Deseado, Santa Cruz Province, Argentina, lat. $47^{\circ} 45^{\prime} 10^{\prime \prime} \mathrm{S}$.

Fig. 16. $\sigma^{7} \mathrm{RV}, \mathrm{NT} / \mathrm{Arg} / \mathrm{At} 7$, ext. lat. $(\times 63)$. Same sample as Fig. 15.

Fig. 17. $\&$ RV, NT/Arg/At 3, ext. lat. $(\times 64)$. Same sample as Fig. 15.

Fig. 18. $\sigma \mathrm{LV}, \mathrm{NT} / \mathrm{Arg} /$ At 6 , ext. lat. $(\times 64)$. Same sample as Fig. 15.

Fig. 19. O LV, NT/Arg/At 6, int. $(\times 64)$. Same sample as Fig. 15.

Fig. 20. $Q \mathrm{LV}, \mathrm{NT} / \mathrm{Arg} / \mathrm{At} 2$, int. $(\times 66)$. Eulittoral, north coast of Tierra del Fuego at Estancia Viamonte, lat. $53^{\circ} 56^{\prime} \mathrm{S}$.

Fig. 21. $\sigma^{7} \mathrm{RV}, \mathrm{NT} / \mathrm{Arg} / \mathrm{At} 4$, int. $(\times 64)$. Same sample as Fig. 15. 


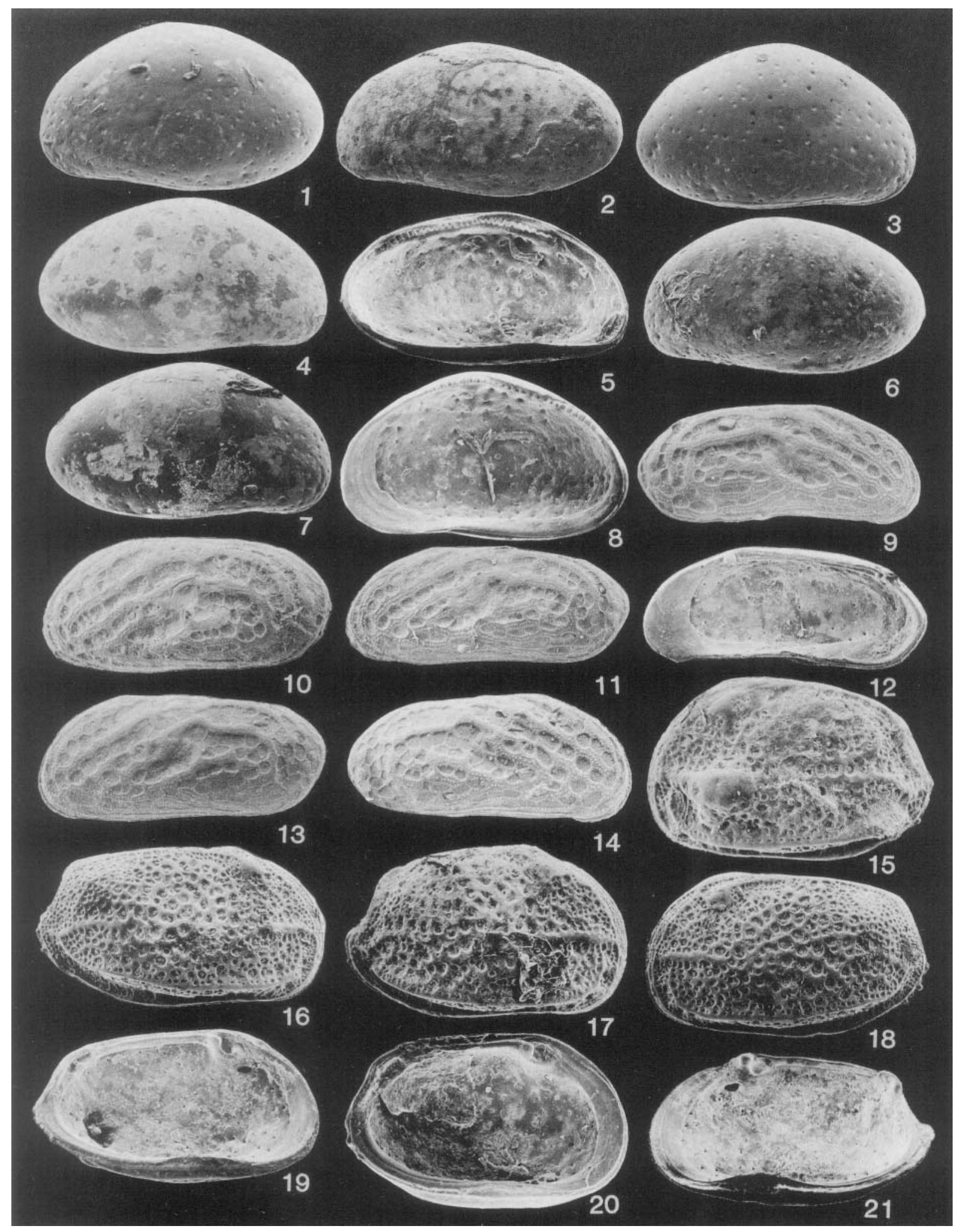


end, widest anteriorly. Approximately 25 simple (rarely bifurcating) radial pore canals anteriorly. Hinge strongly developed, antimerodont; terminal elements long. Adductor muscle scars well-spaced, frontal scar strongly " $v$ "-shaped and vertically disposed.

$\begin{array}{lcc}\text { Dimensions }(\mathrm{mm}) \text {. } & \text { Length } & \text { Height } \\ \text { Holotype, q right valve }(1986,507) & 0.80 & 0.48 \\ \text { Paratype, o left valve }(1986,508) & 0.75 & 0.43 \\ \text { Paratype, \& right valve }(1986,509) & 0.80 & 0.49 \\ \text { Paratype, of left valve }(1986,510) & 0.75 & 0.40 \\ \text { Paratype, q right valve }(1986,511) & 0.77 & 0.43\end{array}$

The first, second and third paratypes are from the same sample as the holotype. The last paratype is from a eulittoral sample of Cladophora collected on the northern shore of the entrance to Puerto Porvenir on the east coast of the Magellan Straits in Chilean Isla Grande (Tierra del Fuego) at about lat. $53^{\circ} \mathrm{S}$.

Distribution. This species has been recorded from eulittoral and sublittoral sediment and algal samples in and around Port Stanley, East Falkland (Coxill MS, 1985); in the eulittoral of Tierra del Fuego (Toy MS, 1985). Chadwick (Ms, 1986) records it dead at two littoral stations on Peninsula Valdex (Lat. $42^{\circ} 47^{\prime} \mathrm{S}$.) and he and Toy encountered dead specimens of the species on the shelf between lat. $50^{\circ} 41.8^{\prime} \mathrm{S}$. and lat. $36^{\circ} 10.4^{\prime} \mathrm{S}$. at depths ranging from $3-131 \mathrm{~m}$.

\section{Subfamily Neocytherideinae Puri, 1957 Genus Papillosacythere gen. nov.}

Type species. Papillosacythere parallela sp. nov. Derivation of name. Latin, referring to the papillate nature of the surface ornament of species of this genus. Diagnosis. A genus of Neocytherideinae with strong horizontal and oblique ribs and interconnecting reticulae. Elevated areas of surface covered with fine lines of pappillae which parallel the rib directions. Hinge strong, modified lophodont. Fulcral point very strongly developed, crescentic.

Remarks. No other species of this genus are known from the Recent but several others, as yet undescribed, can be seen in the Valicenti Collection, from the Oligo-Miocene which is housed at Aberystwyth. This genus differs from all other members of the subfamily in the nature of its strongly ribbed and delicately papillose ornament.

Papillosacythere parallela sp. nov. (P1. 1, figs. 9-14)

1975 New genus and species. Whatley \& Moguilevsky; 517-519; pl. 2, figs. 12-18; pl. 3, fig. 29.

Derivation of name. Latin, with reference to the parallel lines of papillae on the ribs of this species. Diagnosis. Medium-sized, elongate subrectangular.
Surface ornament of low broad ribs which are subhorizontal in the posterior and oblique in the anterior part of the valve and which are interconnected by large reticulae and intricately covered with parallel rows of papillae. Left valve much larger than right.

Holotype. Male right valve (1986, 512).

Material. Some 60 specimens of adults and juveniles, all but a few of which are dead.

Type locality. From the Recent of the estuary of the Rio de La Plata, Bahia Samboronbon, lat. $36^{\circ} 15^{\prime} 05^{\prime \prime} \mathrm{S}$; long. $56^{\circ} 55^{\prime} 05^{\prime \prime} \mathrm{W}$, muddy silt with finely comminuted shell fragments, depth $4 \mathrm{~m}$.

Description. Medium. Elongate subrectangular in lateral view. Thick-shelled. Anterior margin asymmetrically rounded with greatest convexity ventrally; posterior margin subrounded to bluntly pointed, apex at midheight. Dorsal margin short, straight; ventral margin with gentle median concavity. In dorsal view the lateral surface tapers gently towards the anterior and more sharply towards the posterior from the posteromedian point of maximum inflation. Left valve much larger than right with strong overlap ventrally and posterodorsally. Maximum length at mid-height; maximum height at the anterior cardinal angle. Valve surface costate, reticulate and pappilate. The ribs are low and broad and the intercostal areas are reticulate by virtue of being subdivided by low muri which connect the major ribs. The ribs are disposed subhorizontally in the posterior part and obliquely in the anterior part. Parallel rows of delicate papillae extend along the length of the ribs. Ventral surface longitudinally striate. Normal pore canals small and open. Inner lamella wide, particularly anteriorly and inner margin parallel to outer margin. Anterior vestibulum wide, crescentic and deepening anteroventrally; posterior vestibulum smaller, narrower and extending posteroventrally. Radial pore canals few, long and slender; 8-10 anteriorly of which two bifurcate medianly (see Whatley \& Moguilevsky, 1975, pl. 3, fig. 29); 8-10 posteriorly and posteroventrally which always occur as parallel pairs. Hinge lophodont. Anterior element of right valve a boss-like tooth; posterior element blade-like. Adductor scars comprise 4 undivided scars in an oblique row, there is a large single, heart-shaped frontal scar and a strongly incised fulcral point anterodorsal to the adductors. Sexual dimorphism pronounced, the male being more elongate and more pointed posteriorly than the female.

\section{Dimension $(\mathrm{mm})$.}

Holotype, o' right valve $(1986,512)$

Paratype, $\sigma^{T}$ left valve $(1986,513)$

Paratype, 9 carapace $(1986,514)$

Paratype, juv. left valve $(1986,515)$

Paratype, juv. right valve $(1986,516)$
Length Height

$0.49 \quad 0.21$

$0.51 \quad 0.22$

$0.51 \quad 0.25$

$0.45 \quad 0.20$

$0.40 \quad 0.19$ 
Paratypes 1 and 3 are from the same sample as the holotype.

Remarks. The species is more strongly ribbed than the as yet undescribed species known to the authors from the Oligo-Miocene of Patagonia.

Distribution. This species is commonly encountered as dead valves and carapaces in the littoral between lat. $38^{\circ} \mathrm{S}$. and lat. $42^{\circ} 40^{\prime} \mathrm{S}$. and from the shelf between lat. $36^{\circ}$ and lat, $42^{\circ} 23^{\prime} \mathrm{S}$. at depths of $4-57 \mathrm{~m}$. The only live specimens were encountered at lat. $42^{\circ} 23^{\prime} \mathrm{S}$; long. $62^{\circ} 43^{\prime} \mathrm{W}$. at $14 \mathrm{~m}$ on medium sand with some shell fragments and at lat. $42 ; 23^{\prime} \mathrm{S}$.; long. $6243^{\prime} \mathrm{W}$. at $57 \mathrm{~m}$ on fine silty sand with numerous foraminifera and comminuted shell fragments.

Family Hemicytheridae Puri, 1953 Genus Austroaurila gen. nov.

Type species. Cythereis (Cythereis) theeli Skogsberg, 1928.

Derivation of name. Latin, with reference to the evident relationship of this genus to Aurila Pokorny, and its apparent restriction to the South Atlantic.

Diagnosis. A large thick-shelled, subquadrate to subrectangular genus of the Hemicytheridae with straight dorsal margin. Ornament punctate to reticulate with weak ribs. Eye tubercle prominent. Tubercular excresences may be developed $(A$. theeli). Posterior margin subcaudate and upturned in right valve; subrounded to bluntly pointed in left valve. Inner lamella of medium width; very narrow vestibulae at end margins. Numerous anterior radial pore cnals. Hinge strongly holamphidont with slight auriline notch in posterior tooth of right valve. Muscle scars hemicytherid with both central adductors subdivided.

Remarks. This genus differs from Aurila in the shape of the carapace. the dorsal margin of both valves of Austroaurila being straight. Also, in Aurila, only the dorsomedian addluctor scar is subdivided. Austroaurila somewhat resembles Falklandia gen. nov. but the latter has a hemiamphidont hinge with a clearly dentate posterior hinge element in the right valve.

Included willin Austoaurila are the type species, $A$. theeli and also $A$. recurvirostrata (Skogsberg) and $A$. implata (Brady). The genus is apparently confined to shelf and littoral environments in the South Atlantic.

Austroaurila theeli (Skogsberg), 1928

(Pl. 1, figs. 15-21)

pars 1880 Cythere impluta Brady: 76, pl. 26, figs. 6a-d, non $\mathrm{pl} .16$, figs. $3 \mathrm{a}-\mathrm{d} .=$ Austoaurila impluta (Brady), 1880.

1928 Cythereis (Cythereis) theeli Skogsberg: 106, pl. 2, fig. 6, pl. 5, fig. 3, text-fig. 17 .
1979 "Aurila" theeli (Skogsberg), Kaesler, Smith \& Whatley: 239.

Material. 494 adults and juveniles, many live.

Remarks. This species is somewhat similar in shape to Falklandia ephippiata (Skogsberg) from the Falkland Islands, Tierra del Fuego and the littoral and shelf of southern Argentina. However, the dorsal margin of the latter is more horizontal and the anterolateral tubercular excrescence developed in both species in the female left valve, is not accompanied by a similar posteroventral excrescence in $A$. theeli as it is in $F$. ephippiata.

Brady's 1880 material of $A$. impluta included both that species and $A$. theeli. The lectotype selected for the former species by Puri \& Hulings (1976, p. 278, pl. 9, figs. 15,16$)$ is fortunately clearly not $A$. theeli. $A$. impluta differs in lacking the anterolateral tubecle.

Distribution. The type locality of this species is off the coast of the Province of Chubut, in $9 \mathrm{~m}$ of water. Skogsberg (1928) also recorded it from off the coast of Tierra del Fuego. Kaesler et al. (1979) recorded it in the Magellan Straits and Coxill (MS, 1985) found it in littoral samples from East Falkland. Toy (MS. 1985) records it from the littoral of the Beagle Channel, the Magellan Straits, the north coast of Tierra del Fuego and along the littoral of the Argentine Coast to Bahia Solano, some $25 \mathrm{~km}$ north of Comodoro Rivadavia, at about lat. $45^{\circ} 4 n^{\prime}$ S. Chadwick (MS, 1986) encountered the species in the Argentine littoral between Peninsula Valdez (lat. $42^{\circ} 47^{\prime} \mathrm{S}$.) and Mar del Plata (lat. $38^{\circ} \mathrm{S}$.) and on the shelf between lat. $36^{\circ} 12^{\prime} \mathrm{S}$. and $42^{\circ} 23^{\prime} \mathrm{S}$. All the Continental Shelf specimens were dead but the species is commonly encountered live in littoral samples, particularly of algae. It does however, also occur live in littoral sediments, particularly those rich in organic detritus.

\section{Austroaurila impluta (Brady), 1880}

(Pl. 2, figs. 1-5)

pars 1880 Cythere impluta Brady: 76 , pl. 16, figs. 3a-d; non. pl. 26, figs. $6 \mathrm{a}-\mathrm{d}=$ Cythere theeli Skogsberg.

1970 Hemicythere patagonica Rossi de Garcia: 383 , pl. 1, fig. 4.

1976 Cythere impluta Brady, Puri \& Hulings: p. 278 , pl. 9, figs. $15,16$.

Material. 6 dead adult valves.

Remarks. This species differs from $A$. theeli in its greater size, in lacking a median rib and in that the female left valve lacks an anterolateral tubercular excresence. Brady (1880) included both this species and A. theeli in his concept of Cythere impluta. He clearly indicates, however (pp. 76-77), that he had considered the possibility that he was dealing with two species. 
Distribution. Brady's original material of $C$. impluta is from anchor mud at 6 fathoms in Stanley Harbour, Falkland Islands. Rossi de Garcia (1970) recorded the species from Puerto Piramides, Golfo Nuevo, Province of Chubut in beach sand. In the present study it has been found only in a single sediment sample from the shelf at lat $50^{\circ} 41.8^{\prime} \mathrm{S}$.; long. $61^{\circ} 00.6^{\prime} \mathrm{W}$. from $40 \mathrm{~m}$ on fine to medium calcareous sand and silt.

Austroaurila recurvirostrata (Skogsberg), 1982 (Pl. 2, figs. 6, 7)

1928 Cythereis (Cythereis) recurvirostrata Skogsberg: 108, pl. 4, fig. 1; pl. 5, fig. 4; text-fig. 18.

1962 Aurila recurvirostrata (Skogsberg), Hartmann: 236.

1979 "Aurila" recurvirostrata (Skogsberg), Kaesler, Smith \& Whatley: 239.
Material. 2 juvenile valves.

This species is notably larger than either $A$. impluta ro $A$. theeli the mean length of males for the three species being $0.95,0.86$ and $0.78 \mathrm{~mm}$ respectively. It is most similar morphologically to $A$. theeli but differs from that species in its coarser ornament and in the rows of punctae which elaborate the alar rib. It also lacks the anterolateral tubercle in the female left valve which is such a diagnostic feature of $A$. theeli.

Distribution. Skogsberg (1928) encountered this species on the Burwood Bank (lat. $53^{\circ} 45^{\prime} \mathrm{S}$.; long. $61^{\circ} 10^{\prime} \mathrm{W}$.) at depths of $137-150 \mathrm{~m}$ on mussel sand with stones. Hartmann (1962) found it at two littoral localities in the southern Chilean province of Magallanes. Kaesler et al. (1979) record it from the Magellan Straits. In the present study, neither Toy nor Chadwick encountered the species but Coxill recovered two dead juveniles from a kelp (Macrocystis) holdfast in Stanley Harbour, Falkland Islands.

\section{Explanation of Plate 2}

Figs. 1-5. Austroaurila impluta (Brady), 1888.

All from calcareous sand and silt at $131 \mathrm{~m}$. lat. $50^{\circ} 41.8^{\prime} \mathrm{S}$.; long. $61^{\circ} 00.6^{\prime} \mathrm{W}$.

Fig. 1. $\sigma^{\prime} \mathrm{LV}, \mathrm{NT} / \mathrm{Arg} / \mathrm{Ai} 3$, ext. lat. $(\times 57)$.

Fig. 2. $q$ RV, NT/Arg/Ai 4, ext. lat. $(\times 60)$.

Fig. 3. $Q$ LV, NT/Arg/Ai 1 , ext. lat. $(\times 57)$.

Fig. 4. \& RV, NT/Arg/Ai 2, ext. lat. $(\times 57)$.

Fig. 5. $q$ RV, NT/Arg/Ai 5, ext. lat. $(\times 58)$.

Figs. 6, 7. Austroaurila recurvirostrata (Skogsberg), 1928.

Both specimens from sublittoral Macrocystis holdfast, just west of cemetry, Port Stanley, East Falkland.

Fig. 6. juv. LV, DJC/134, ext. lat. $(\times 86)$.

Fig. 7. juv. LV, DJC/136, int. $(\times 86)$.

Figs. 8-14. Falklandia ephippiata (Skogsberg), 1928.

Fig. 8. $\sigma^{7} \mathrm{LV}$, NT/Arg/Fe 5, ext. lat. $(\times 57)$. Eulittoral, Puerto Deseado, Santa Cruz Province, Argentina, lat. $47 ; 45^{\prime} 10^{\prime \prime} \mathrm{S}$.

Fig. 9. $\mathrm{R}$ RV, NT/Arg/Fe 4, ext. lat. $(\times 60)$. Same sample as Fig. 8.

Fig. 10. $q$ LV, NT/Arg/Fe 3, ext. lat. $(\times 62)$. Sublittoral Macrocystis holdfast, Bahia Cavendish, Santa Cruz Province, Argentina, lat. $47^{\circ} 45^{\prime} \mathrm{S}$.

Fig. 11. $O \mathrm{LV}, \mathrm{NT} / \mathrm{Arg} / \mathrm{Fe} 1$, int. $(\times 60)$. Same sample as Fig. 8.

Fig. 12. O RV, NT/Arg/Fe 6, ext. lat. $(\times 58)$. Same sample as Fig. 8.

Fig. 13. $\sigma^{7} \mathrm{LV}, \mathrm{NT} / \mathrm{Arg} / \mathrm{Fe} 5$, int. $(\times 57)$. Same sample as Fig. 8.

Fig. 14. $q$ LV, NT/Arg/Fe 3, int. $(\times 62)$. Same sample as Fig. 8.

Figs. 15-19. Meridionalicythere discophora (Skogsberg), 1928.

All from eulittoral algae, north shore of Beagle Channel, just west of Ushuaia, lat. $54^{\circ} 50^{\prime} \mathrm{S}$.

Fig. 15. O RV, NT/Arg/Md 2, ext. lat. $(\times 63)$.

Fig. 16. O LV, NT/Arg/Md 1, ext. lat. $(\times 63)$.

Fig. 17. + RV, NT/Arg/Md 3, int. $(\times 63)$.

Fig. 18. O RV, NT/Arg/Md 5, ext. lat. $(\times 67)$.

Fig. 19. OT LV, NT/Arg/Md 4, ext. lat. $(\times 62)$.

Figs. 20, 21. Meridionalicythere mesodiscus (Skogsberg), 1928.

All from eulittoral algae, norther shore of Beagle Channel, just west of Ushuaia, lat. $54^{\circ} 50^{\prime} \mathrm{S}$.

Fig. 20. o RV, NT/Arg/Mm 2, ext. lat. $(\times 65)$.

Fig. 21. $\mathrm{O}$ LV, NT/Arg/Mm 1, ext. lat. $(\times 63)$. 


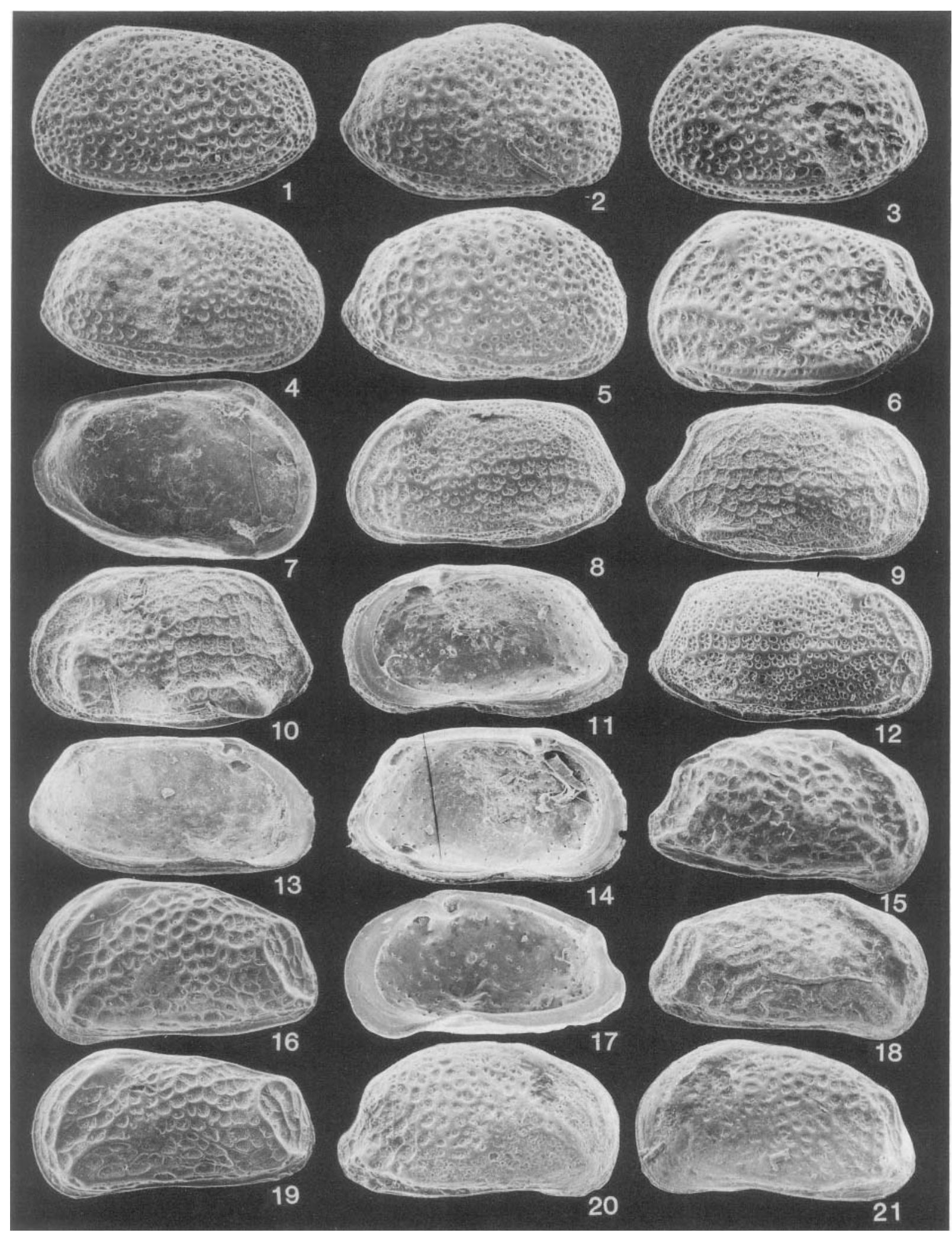


Genus Falklandia gen. nov.

Type species. Cythereis (Cythereis) ephippiata Skogsber, 1928.

Derivation of name. With reference to the type locality of the type species, Berkley Straits, Port Louis, Falkland Islands.

Diagnosis. A large subquadrate to subrectangular genus of the Hemicytheridae with subcaudate posterior margin. Carapace thick-shelled, somewhat tumid and covered with reticulate ornament the fossae of which are secondarily punctate with usually 4 punctae per fossa. Eye tubercle large and prominent. Male with less well developed alar ridge then female; female left valve with well developed anterolateral tubercular excrescense. Wide inner lamella with narrow vestibulae at each end margin. Numerous simple radial pore canals anteriorly. Hinge robustly developed, hemiamphidont, the posterior terminal element of the right valve being a dentate bar with 5-7 small oval teeth which increase in size distally. Adductors with two central scars subdivided. Male considerably more elongate than female. Remarks. This as yet monotypic genus is apparently confined to the South Atlantic and southernmost South America. Falklandia somewhat resembles certain species of Austroaurila, particularly A. theeli (Skogsberg). The two genera, however can be readily distinguished on hingement, the latter being holamphidont and the former hemiamphidont. Although the female left valves of both $F$. ephippiata and $A$. theeli develop an anterolateral excrescence, that of the former is aligned vertically while that of the latter is either hemispherical or aligned horizontally and is almost smooth.

\section{Falklandia ephippiata (Skogsberg), 1928}

(Pl. 2, figs. 8-14)

1920 Cythereis sp. Skogsberg: 145.

1928 Cythereis (Cythereis) ephippiata Skogsberg: 100, pl. 2, fig. 7 ; pl. 3, fig. 3; pl. 5, fig. 2; text-fig. 16 .

1962 Aurila ephippiata (Skogsberg), Hartmann: 237.

Material. 268 adults and juveniles, many live specimens.

Remarks. As in $A$. theeli, only the female left valve has a tubercle anterolaterally. The function of this structure is unknown.

Distribution. This species was originally described by Skogsberg from the Berkley Straits and Carenage Creek, Port Louis, Falkland Islands. Coxill (MD, 1985) recovered 18 specimens in eulittoral and sublittoral algal samples from Stanley Harbour, Eliza Cove and the Estuary of the Murrel River, all in East Falkland, but failed to encounter the species in samples from Port Louis. Hartmann found it in the littoral of Tierra del Fuego. Toy (MS, 1985) recovered 250 specimens from littoral algal and sediment samples from the Beagle
Channel, Magellan Straits and the Argentine coast north to Puerto Deseado (lat. $54^{\circ} 50^{\prime} \mathrm{S}$. to lat. $47^{\circ} 10^{\prime}$ S.). The species was absent from shelf sediment samples and Chadwick failed to recover it in his study of the Argentine littoral Ostracoda north of lat $.45^{\circ} \mathrm{S}$.

$$
\text { Meridionalicythere gen. nov. }
$$

Type species. Cythereis (Cythereis) discophora Skogsberg, 1928.

Derivation of name. With reference to the apparent restriction of this genus to the South Atlantic.

Diagnosis. A genus of the Hemicytheridae with large subrectangular to subtrapezoidal carapace; maximum height at the anterior cardinal angle. Dorsal margin, straight and inclined towards the posterior, or convex. Anterior margin well rounded; posterior subtruncate to bluntly pointed, apex below mid-height. Ornament reticulate and/or punctate, with or without costae. Dorsal loop and subalar ridge more or less well developed. Shell thick. Subcentral tubercle present but not prominent. Eye tubercle small, prominent. Inner lamella of median width with very narrow vestibulae at each margin. Hinge holamphidont, robustly developed. Posterior terminal element of right valve a boss-like tooth or a smooth arcuate bar. The two central adductor scars are subdivided. Strongly sexually dimorphic, males much more elongate than females.

Remarks. This genus is based on the three specis $M$. discophora, $M$. mesodiscus and $M$. taeniata (all Skogsberg, 1928). Meridionalicythere differs from Aurila in shape, the nature of the adductor scars and in hingement. From Procythereis Skogsberg, it differs in both shape and ornament and in its much less strongly developed alar ridge. From Hemicythere it differs in being less subrectangular, in possessing a subcentral tubercle, a dorsal loop and an alar ridge. The genus is apparently confined to the S. W. Atlantic and southernmost South America.

Meridionalicythere discophora (Skogsberg), 1928 (Pl. 2, figs. 15-19)

1928 Cythereis (Cythereis) discophophora Skogsberg: 83, pl. 2, fig. 1; text-fig. 13.

1962 Aurila discophora Skogsberg, Hartmann: 237.

1979 “Aurila discophora" Skogsberg, Kaesler, Smith \& Whatley: 239 .

Material. 191 adult and juveniles, including many live specimens.

Remarks. The mean length of this species $(0.77 \mathrm{rmm})$ is slightly greater than that of $M$. mesodiscus $(0.75 \mathrm{~mm})$ and considerably greater than $M$. taeiniata $(0.69 \mathrm{~mm})$. $M$. discophora is the most strongly reticulate of the three species, its dorsal loop is more strongly developed than that of $M$. mesodiscus but slightly less than that of M. taeniata. 
Distribution. Skogsberg's original material was from Carenage Creek, Port Louis, Falkland Islands. Coxill (MS, 1985) recorded the species abundantly in littoral algae from around the Port Stanley area of East Falkland. Toy (MS, 1985) found more than 100 specimens from eulittoral algal and sediment samples from the Beagle Channel, the Magellan Straits and the Argentine coast north to Caleta Olivia, in the Province of Santa Cruz, at about lat. $46^{\circ} 30^{\prime} \mathrm{S}$. The species was absent from shelf sediment samples and Chadwick (MS, 1986) did not encounter it in his study of the Ostracoda north of lat. $45^{\circ}$.

Meridionalicythere mesodiscus (Skogsberg), 1928 (Pl. 2, figs. 20, 21; PI. 3, figs. 1-9)

1928 Cythereis (Cythereis) mesodiscus Skogsberg: 87, pl. 2, figs. 2, 3; pl. 4, fig. 7, text-fig. 14 .

1962 Aurila mesodiscus (Skogsberg), Hartmann: 237.

1979 "Aurila" mesodiscus (Skogsberg), Kaesler, Smith \& Whatley: 239.

Material. 399 adults and juveniles, many live.

Remarks. This species differs from other members of the genus in the very elongate shape of the male and in the nature of its ornament. The posterodorsal loop is very weakly developed and the ornament comprises irregular reticulae posteriorly, subhorizontally aligned punctae within a reticulum in which the horizontal murae predominate medianly, and a weak irregular reticulum anteriorly, containing within the fossae a delicate secondary punctation. The subalar ridge is only weakly developed in this species. All these characters serve to distinguish this species from other members of the genus.

Distribution. Very abundantly distributed throughout the area studied. Skogsberg (1928) first recorded it from a depth of $9 \mathrm{~m}$ off Puerto Madryn, Province of Chubut, at approximately lat. $42^{\circ} 50^{\prime} \mathrm{S}$. and also from off Isla Nueva, south of the Beagle Channel. Hartmann (1962) recorded it from the littoral of Magallanes Province, southern Chile and Kaesler et al. from the Magellan Straits. Coxill (MS, 1985) found 29 specimens from eulittoral and upper sublittoral environments around the Port Stanley area of East Falkland. Toy (MS, 1985) records the species in algal samples and sediments of various types from the littoral of the Beagle Channel, the northern coast of Tierra del Fuego, the Magellan Straits and the Argentine coast north to Caleta Olivia, near the boundary between the provinces of Santa Cruz and Chubut, at about lat. $45^{\circ} 40^{\prime} \mathrm{S}$. Chadwick (NS, 1986) recovered the species in similar environments from the beach at Puerto Madryn (lat. $40^{\circ} 40^{\prime} \mathrm{S}$.), in the Province of Chubut north to San Antonia Oeste (lat. $42^{\circ} 50^{\prime} \mathrm{S}$.) in the Province of Rio Negro. The total latitudinal range of this species, from $54^{\circ} 50^{\prime} \mathrm{S}$. to $40^{\circ} 40^{\prime} \mathrm{S}$. is considerable. It was not encountered in sediment samples from the shelf.

Meridionalicythere taeniata (Skogsberg), 1928

(Pl. 3, figs. 10-14)

1928 Cythereis (Cythereis) taeniata (Skogsberg): 72, pl. 1, fig. 6; pl. 4, fig. 5; text-fig. 11.

1962 Aurila ? taeniata (Skogsberg), Hartmann: 236.

1979 "Aurila" taeniata (Skogsberg), Kaesler, Smith \& Whatley: 239.

Material. 214 adults and juveniles, including numerous live individuals.

Remarks. This is the smallest species of the genus. It differs from other species in its more convex dorsal margin, particularly in the female, in its irregularly reticulate and secondarily punctate ornament and in the possession of large pore conuli. It also differs in its possession of a very strong posterodorsal loop and a strong ocular ridge which parallels the anterior margin and an anteromarginal ridge which extends distal to it. Distribution. Skogsberg's material was collected from Carenage Creek, Port Louis, East Falkland (lat. $51^{\circ} 32^{\prime} \mathrm{S}$.; long. $58^{\circ} 7^{\prime} \mathrm{W}$.) at a depth of $1 \mathrm{~m}$ in sand with Codium. Coxill (MS, 1985) recorded 22 specimens, living and dead, from eulittoral and sublittoral and sediment samples in the general area of Port Stanley, Falkland Islands. Hartmann (1962) recovered the species from the littoral of Rio El Ganso, Magallanes Province, southern Chile and Kaesler et al. found it in the Magellan Straits. Toy (MS, 1985) recovered 192 specimens from mainly eulittoral algal samples in the Beagle Channel and Magellan Straits. Its most northern record in Toy's study is at Caleta Olivia (dead) at about lat. $46^{\circ} 30^{\prime} \mathrm{S}$. It was not encountered on the shelf nor by Chadwick in his study of the faunas north of lat. $45^{\circ} \mathrm{S}$.

\section{? Meridionalicythere $\mathrm{sp}$. \\ (Pl. 3, figs. 15-18)}

Material. 2 carapaces with soft parts, 42 left valves, 47 right valves, all juvenile.

Remarks. This smooth species, although common in its occurrence is represented solely by juveniles. We have considered the possibility, because of the fact that we failed to encounter any specimens which could possibly be considered adults of this species, that what we have considered to be the penultimate instar, despite its possession of distinctly juvenile internal characters, might represent a neotonous adult. This possibility remains but since we are unable to demonstrate this beyond doubt, we have left the species in open nomenclature. Similarly, it can only be tentatively assigned to Meridionalicythere, to which it is similar in shape and in possessing a weak subcentral tubercle and subalar ridge. The hinge is merodont and the inner 
lamella very narrow and weakly calcified.

Distribution. This species is widely distributed in the eulittoral along the Argentine coast from San Antonio Oeste, Province of Rio Negro (lat. $40^{\circ} 40^{\prime}$ S.) to Mar del Plata, Province of Buenos Aires (lat. $38^{\circ} \mathrm{S}$.). It was also recovered from the shelf, in the estuary of the Rio de La Plata, from lat. $42^{\circ} 23^{\prime} \mathrm{S}$. to off the coast of Brazil at lat. $24^{\circ} 02^{\prime} \mathrm{S}$.

\section{ACKNOWLEDGEMENTS}

R.C.W. wishes to express his gratitude to his many Argentine friends and colleagues for all their assistance during the collection of the material on which this study is based. Alicia Moguilevsky, then of the Dept. of Biology, University of Buenos Aires (now Dept. Geology, U.C.W.) assisted in the collection of almost all the littoral samples from the Beagle Channel to the River Plate. Alicia Boraso and Maria-Luz Piriz, both of the Dept. of Biology, Buenos Aires, were responsible for identifying algae in the field. Miguel Manceñido, of the Dept. of Invertebrate Palaeontology, University of La Plata, was a tower of strength on the first collecting expedition to Patagonia.

The senior author also wishes to thank the Hydrographic Service of the Argentine Navy for allowing him access to a large number of sediment samples from the
Continental Shelf. Thanks are particularly due to Capitan de Fregata Lara for his help and interest in the project.

The British Antarctic Survey and the Governor of the Falkland Islands are thanked for all their assistance during the collecting expedition to East Falkland.

Thanks are also due to Sr. Jorge Mennuchi for all his assistance in the laboratory preparation of the samples in the Department of Micropalaeontology, University of La Plata. John Chadwick wishes to acknowledge a N.E.R.C. Studentship, held during his Magister studies. Caroline Maybury has critically read the MS and helped in many other ways. Our sincere thanks to her and to everyone associated with the project.

Manuscript received August 1986

Revised manuscript accepted December 1986

\section{Explanation of Plate 3}

Figs. 1-9. Meridionalicythere mesodiscus (Skogsberg), 1928.

All from eulittoral algae, north shore of Beagle Channel, just west of Ushuaia, lat. $54^{\circ} 50^{\prime} \mathrm{S}$.

Fig. 1. $\sigma^{7} \mathrm{LV}, \mathrm{NT} / \mathrm{Arm} / \mathrm{Mm} \mathrm{4}$, ext. lat. $(\times 70)$.

Fig. 2. $ᄋ \mathrm{LV}, \mathrm{NT} / \mathrm{Arg} / \mathrm{Mm} 1$, int. $(\times 63)$.

Fig. 3. o' RV, NT/Arg/Mm 5, ext. lat. $(\times 71)$.

Fig. 4. $O \mathrm{LV}, \mathrm{NT} / \mathrm{Arg} / \mathrm{Mm} 13$, ext. lat. $(\times 66)$.

Fig. 5. O' LV, NT/Arg/Mm 4, int. $(\times 70)$.

Fig. 6. $9 \mathrm{RV}, \mathrm{NT} / \mathrm{Arg} / \mathrm{Mm} 14$, ext. lat. $(\times 66)$.

Fig. 7. $O \mathrm{LV}, \mathrm{NT} / \mathrm{Arg} / \mathrm{Mm} 15$, lat. $(\times 66)$.

Fig. 8. ㅇ RV, NT/Arg/Mm 3, int. $(\times 64)$.

Fig. 9. $q \mathrm{RV}, \mathrm{NT} / \mathrm{Arg} / \mathrm{Mm} 3$, ext. lat $(\times 64)$.

Figs. 10-14. Meridionalicythere taeniata (Skogsberg), 1928.

All from the same locality as the previous species.

Fig. 10. $\&$ LV, NT/Arg/Mt 1, ext. lat. $(\times 71)$.

Fig. 11. + RV, NT/Arg/Mt 2, ext. lat. $(\times 72)$.

Fig. 12. O RV, NT/Arg/Mt 4, ext. lat. $(\times 74)$.

Fig. 13. O LV, NT/Arg/Mt 3, ext. lat. $(\times 72)$.

Fig. 14. $q$ RV, NT/Arg/Mt 2, int. $(\times 72)$.

Figs. 15-18.? Meridionalicythere sp.

All from algae in ria, immediately south of San Antonio Oeste, Rio Negro Province, Argentina, lat. $40^{\circ} 40^{\prime} \mathrm{S}$.

Fig. 15. juv. LV, JC/Arg/345. Sublittoral.

Fig. 16. juv. RV, JC/Arg/345a. Sublittoral.

Fig. 17. juv. RV, JC/Arg/347. Eulittoral.

Fig. 18. juv. RV, JC/Arg/246. Eulittoral. 

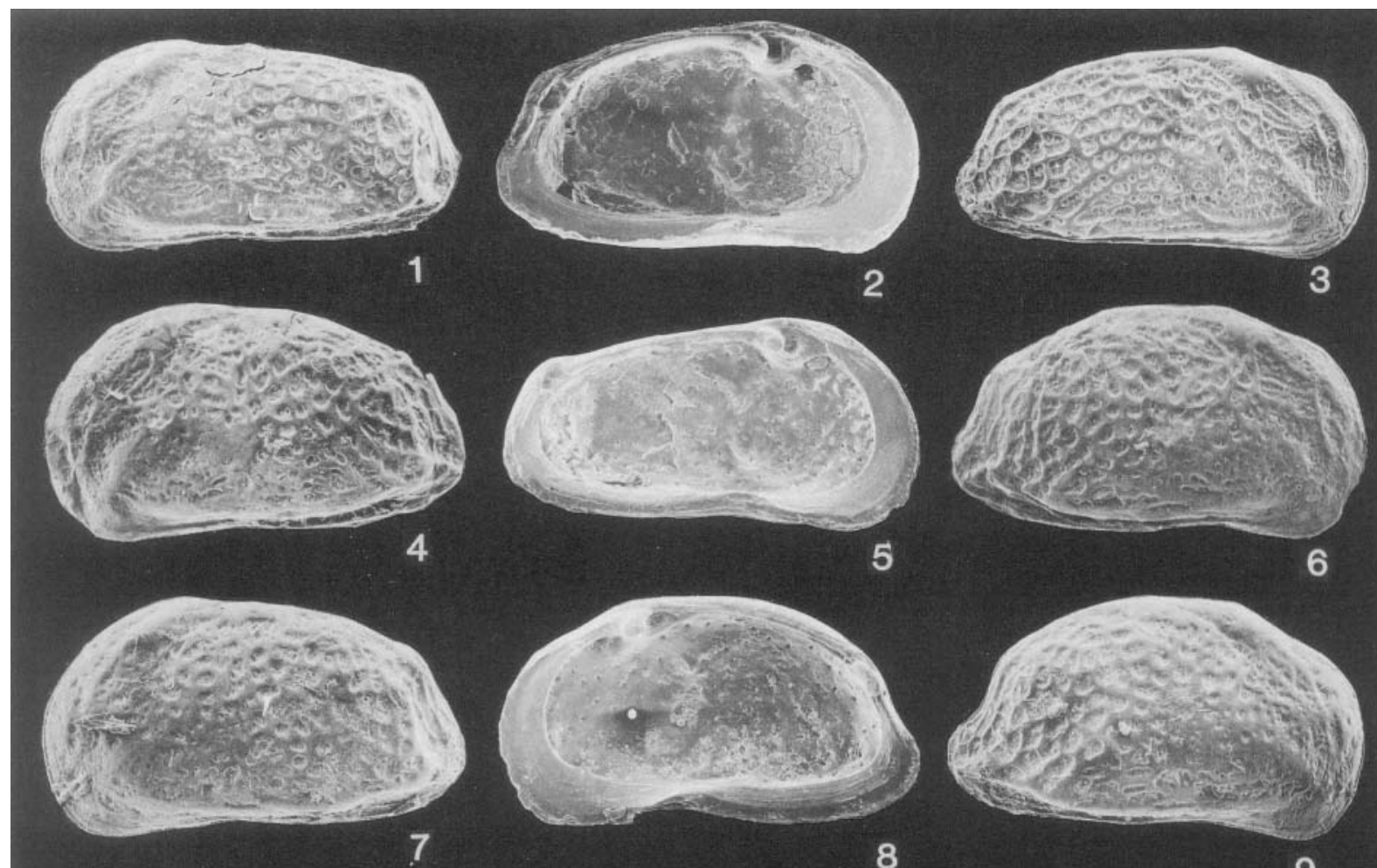

8
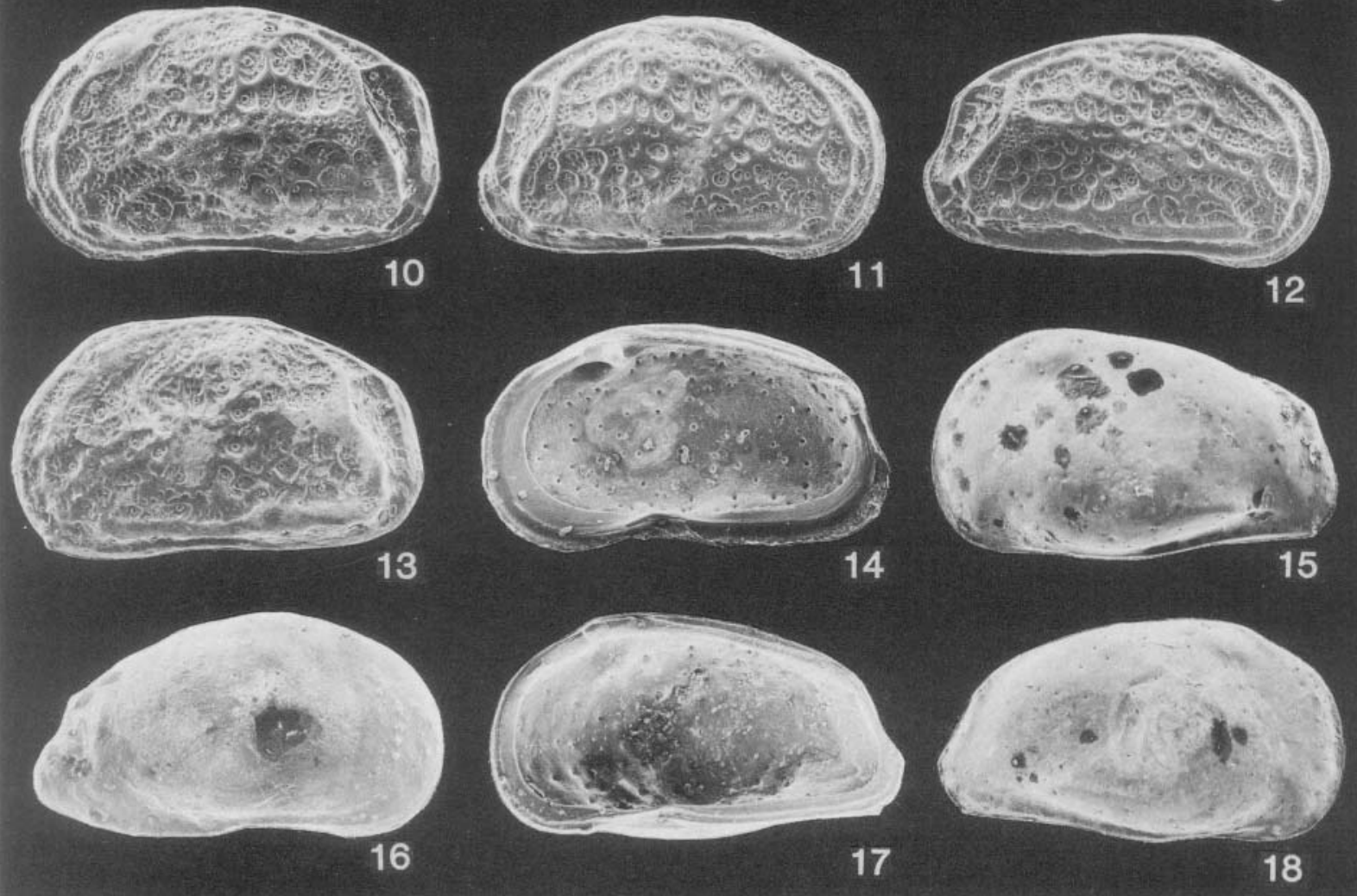


\section{REFERENCES}

Brady, G. S. 1880 . Report on the scientific results of the voyage of H.M.S. Challenger during the years 1873-1876. Rep. Sci. Res. Voyage H.M.S. Challenger, Zool. 1 (3): Ostracoda, 184 pp., 44 pls.

Chadwick, J. M. 1986. Recent littoral and shelf Ostracoda from Brazil and Argentina south to $45^{\circ} \mathrm{S}$. Unpub. M.Sc. thesis, Univ. Wales, 292 pp., 10 pls.

Coxill, D. J. 1985. Recent podocopid Ostracoda from deep waters of the South Scotia Sea, littoral and shelf of Antarctica, and the littoral of East Falkland. Unpub. M.Sc. thesis, Univ. Wales, 455 pp., 9 pls., 4 text-figs.

Hartmann, G. 1962. In Hartmann-Schroeder, G. \& Hartmann, G. Zur Kenntnis des Eulittorals der chilenischen Pazifikkuste und der argentinischeen Kuste Sudpatagoniens unter besonderer Berucksichtigung der Polychaeten und Ostracoden. Mitt. Hamburg Zool. Mus. Inst., 60, 169-270, 223 figs.

Kaesler, R. L., Smith, S. \& Whatley, R. C. 1979. Ostracoda and petroleum pollution in the Strait of Magellan. Proc. 7 th Int. Symposium on Ostracoda, Beograd. Serbian Geological Society, 237-242.
Moguilevsky, A. 1977. The taxonomy, morphology and distribution of some podocopid Ostracoda from Argentinian waters. Unpub. M.Sc. thesis, Univ. Wales, 238 pp., 40 pls.

Puri, H. S. \& Hulings, N. C. 1976. Designation of lectotypes of some ostracodes from the Challenger Expedition. Bull. Br. Mus. nat. Hist. (Zool.), 29, (5), 249-315, 27 pls., 14 text-figs.

Rossi de Garcia, E. 1970. Un nouveau genre d'ostracodes des cotes de Patagonie, Republique Argentine. 4th Colloq. Africa Micropal., 379-386, 2 pls.

Skogsberg, T. 1928. Studies on marine ostracods. Part 2. External morphology of the genus Cythereis with description of 21 new species. Calif. Acad. Sci. Occasional Papers, 15, 1-155, 23 text-figs. pls. 1-6.

Toy, N. 1985. Recent littoral and shelf Ostracoda from Argentinian and Chilean waters south of $45^{\circ} \mathrm{S}$. Unpub. M.Sc. thesis, Univ. Wales, 171 pp., 7 pls.

Whatley, R. C. \& Moguilevsky, A. 1975. The family Leptocytheridae in Argentine waters. Bull. Am. Paleont., 65, No. 282, 501-527, 3 pls. 